\title{
Yeast two-hybrid and pull-down assays propose an interaction between P50 of apple chlorotic leaf spot virus and PR-10 of Malus sylvestris cv. R12740-7A
}

\author{
Y. WANG, N. LI, X. ZHAO, J. HU, Y. HE, T. HU, S. WANG, Y. WANG*, K. CAO \\ College of Plant Protection, Agricultural University of Hebei, Baoding Hebei, P. R. China
}

Received February 2, 2017; revised February 6, 2017; accepted October 10, 2017

\begin{abstract}
Summary. - Apple chlorotic leaf spot virus (ACLSV) movement protein (P50) is involved in cell-to-cell transport and influences the long-distance spread of silencing activity. Previously, we obtained 69 P50-interacting proteins from Malus sylvestris cv. R12740-7A and using bioinformatics analyzed their biological functions. In this study, we used the GAL4-based two-hybrid yeast system and His pull-down assays to confirm an interaction between PR-10 of M. sylvestris cv. R12740-7A and ACLSV P50. Our results provide a theoretical basis for further research on the biological function of PR-10 in ACLSV infection and the interacting mechanism between host and virus.
\end{abstract}

Keywords: apple chlorotic leaf spot virus; Malus sylvestris cv. R12740-7A; P50; PR-10

Apple chlorotic leaf spot virus (ACLSV) infects a wide range of fruit trees, including apples, pears, plums, quinces, cherries, apricots and peaches (German-Retana, et al., 1997; Németh, 1986). It is the most frequently encountered virus in almost all apple orchards in China, often causing latent infections (Desvignes et al., 1992; Waterworth, 1993). Although most strains are latent in apple trees, others are responsible for apple russet ring spot, apple top working disease and lethal decline of apple on some rootstock varieties (Desvignes and Boyé, 1989). The virions of ACLSV are flexuous filamentous particles of $720 \mathrm{~nm}$ $\times 12 \mathrm{~nm}$ (Brunt et al., 1996). The ACLSV genome consists of $7,555 \mathrm{~kb}$ long single-stranded RNA molecule, excluding the poly-A tail. Its open reading frames (ORFs) 1, 2 and 3 encode proteins with molecular masses of $216.5,50.4$ and $21.4 \mathrm{kDa}$, respectively (German et al., 1990). The $216.5 \mathrm{kDa}$ ORF encodes a protein possibly involved in viral replication, the $50.4 \mathrm{kDa}$ protein is a putative movement protein, and the $21.4 \mathrm{kDa}$ product is the viral coat protein (German et al., 1992).

*Corresponding author. E-mail: wyn3215347@163.com, phone: +863127528157. Y. Wang and N. Li contributed equally to this paper.

Abbreviations: ACLSV = apple chlorotic leaf spot virus; TMV = tobacco mosaic virus; $\mathrm{P} 50=$ movement protein; $\mathrm{PR}-10=$ pathogenesis-related protein; $\mathrm{Y} 2 \mathrm{H}=$ yeast two-hybrid system
The ACLSV movement protein (P50) is reported to be multifunctional. Observation of transgenic leaves from Nicotiana occidentalis expressing the $50 \mathrm{kDa}$ protein fused to enhanced green fluorescent protein (EGFP) revealed that ACLSV P50 targets plasmodesmata and accumulates in the sieve elements of transgenic plant leaves (Yoshikawa, et al., $1999,2006)$. The protein spreads from cells that produce it into neighboring cells, enabling cell-to-cell trafficking of GFP when P50 and GFP (P50-GFP) are co-expressed in the leaf epidermis. P50-GFP could complement the local spread of the P50-deficient virus when expressed transiently in the leaf epidermis of Chenopodium quinoa. Expression of P50-GFP in protoplasts resulted in the production of tubular structures protruding from the protoplast surface (Satoh et al., 2000). ACLSV P50 can also interfere with the intra- and inter-cellular targeting and tubule-inducing activity of the $39 \mathrm{kDa}$ putative movement protein of grapevine berry inner necrosis virus (Isogai et al., 2003). This protein also has two independently active, single-stranded nucleic acid-binding domains (Isogai and Yoshikawa, 2005). In addition to these functions, a recent study revealed that P50 functions as a silencing suppressor, inhibiting systemic silencing in $N$. benthamiana without interfering with local silencing (Yaegashi et al., 2007). Other data suggest that P50 is a unique suppressor, specifically inhibiting the long-distance move- 


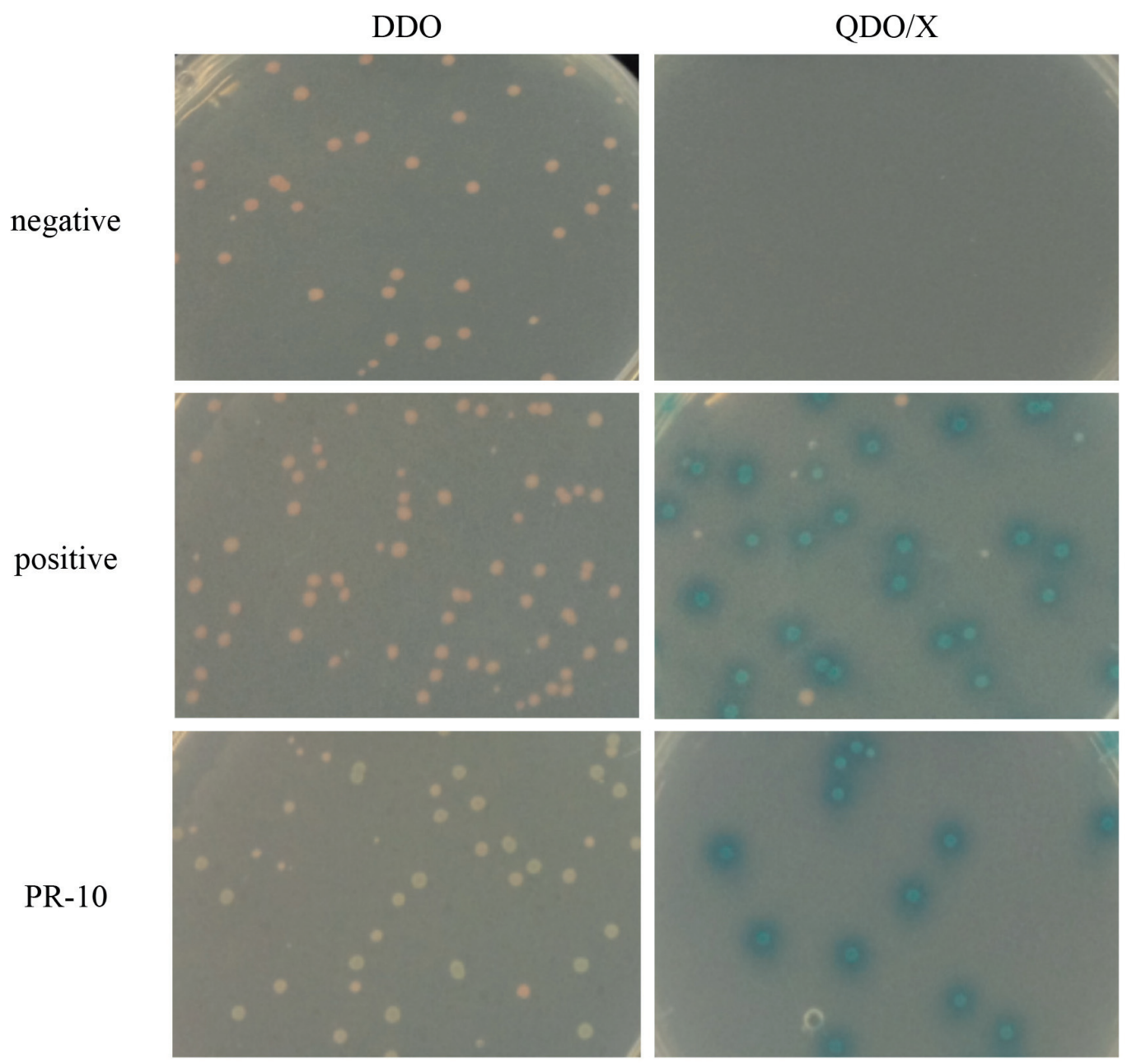

Fig. 1

Interaction between the pathogenesis-related protein (PR-10) from Malus sylvestris and the movement protein (P50) from apple chlorotic leaf spot virus in a yeast two-hybrid assay

Negative control: yeast Y2H gold harboring pGBKT7-Lam and pGADT7-T. Positive control: yeast Y2H gold harboring pGBKT7-53 and pGADT7-T. PR-10: yeast Y2H gold harboring pGBKT7-P50 and pGADT7-PR-10. DDO: SD/-Leu/-Trp medium. QDO/X: SD/-Ade/-His/-Leu/-Trp/X- $\alpha$-Gal medium.

ment of silencing signals through phloem cells (Yaegashi et al., 2008). Although many functions of P50 have been reported, little is known about the molecular pathway by which ACLSV P50 interacts with its host. The host proteins essential for interaction with P50 remain largely unknown.

To address this issue, our group used a high-throughput yeast two-hybrid (Y2H) screening by the Matchmaker ${ }^{\text {Tw }}$ Gold Yeast Two-Hybrid system (Clontech, BD Biosciences, USA) to screen P50-interacting proteins from cDNA library of M. sylvestris cv. R12740-7A (Duan et al., 2014). To test whether the P50 of ACLSV and the PR-10 from M. sylvestris cv. R12740-7A, which was one of P50-interacting proteins obtained by $\mathrm{Y} 2 \mathrm{H}$ system, interact physically, we amplified the full-length sequence of PR-10 from the corresponding cDNA clone using PCR, and then cloned it into pGADT7, using the EcoRI/BamHI sites, to form pGADT7-PR-10. pGADT7-PR10 was then used as prey and $\mathrm{P} 50$ as bait in the $\mathrm{Y} 2 \mathrm{H}$ system. Bait and prey plasmids were mixed and co-transformed into $\mathrm{Y} 2 \mathrm{H}$ gold yeast strain. Co-transformation of pGBKT7-53 and pGADT7-T was used as positive controls and pGBKT7-Lam and pGADT7-T as negative controls. Self-activation of P50 and PR-10 has been ruled out in our previous study (data not shown). pGBKT7-P50 and pGADT7-PR-10 were then co-transformed into yeast strain $\mathrm{Y} 2 \mathrm{H}$ gold, and the mixture was incubated for $3-5$ days at $30^{\circ} \mathrm{C}$ on SD/-Leu/-Trp (DDO) medium and SD/-Ade/-His/-Leu/-Trp/X- $\alpha-$ Gal medium (QDO/X). Protein interactions were monitored by comparing the growth and color of the yeast with the positive and 
negative controls. The results showed that the yeast strain Y2H gold harboring pGBKT7-P50 and pGADT7-PR-10 (AD-PR-10/BD-P50) grew well in the medium lacking tryptophan and leucine, and formed clear blue colonies in QDO/X medium, indicating an interaction between P50 and PR-10 (Fig. 1).

To confirm the interaction between PR-10 and P50, we conducted an in vitro pull-down assay. ORF of viral protein P50 in vector pET21a containing His-tag and ORF of $M$. sylvestris cv. R12740-7A PR-10 without His-tag were transformed into E. coli Rosetta (DE3) (Novagen). The cells were induced with $0.1 \mathrm{mmol} / \mathrm{l} \mathrm{IPTG}$, harvested by centrifugation, and then washed with Tris-buffered saline (TBS, $25 \mathrm{mmol} / \mathrm{l}$ Tris, $0.15 \mathrm{~mol} / \mathrm{l} \mathrm{NaCl}, \mathrm{pH} 7.2$ ) at $4^{\circ} \mathrm{C}$. Then $0.1 \mathrm{~mol} / \mathrm{l}$ phenylmethanesulfonyl fluoride was added to the cells to a final concentration of $1 \mathrm{mmol} / \mathrm{l}$ and then sonicated on ice. The lysate was centrifuged at $11,000 \times \mathrm{g}$ for $10 \mathrm{~min}$ and the precipitate and supernatant were collected for analysis on SDS-PAGE. The virus movement protein (P50) was purified with a $6 \times$ His-tagged protein purification kit (Cwbiotech, China) according to the manufacturer's instructions and $5 \mu \mathrm{l}$ of the purified protein was separated on SDS-PAGE (Fig. 2). We used western blot analysis with His-HRP to confirm that P50 contained His-tag (Fig. 2, lanes 8-9).

A His pull-down assay was performed using the Pierce ${ }^{\mathrm{Tm}}$ His Protein interaction pull-down kit (Pierce Biotechnology, USA) according to the instructions of the manufacturer. Briefly, the purified His-tag fusion P50 protein was immobilized on HisPur Cobalt resin for at least $30 \mathrm{~min}$ at $4^{\circ} \mathrm{C}$ with gentle rocking and then each column placed in a collection tube. The tubes were centrifuged at 1,250 $\times \mathrm{g}$ for $1 \mathrm{~min}$ and the supernatant was collected (= bait flow-through). The columns were then washed five times with wash solution. Approximately $800 \mu \mathrm{l}$ of prepared PR-10 protein sample was then added to the columns and incubated for at least $1 \mathrm{~h}$ at $4^{\circ} \mathrm{C}$ on a gently rotating platform. The columns were inserted into collection tubes and centrifuged at $1,250 \times \mathrm{g}$ for 30-60 s (= prey flow-through). The columns were washed several times using $400 \mu$ lof wash solution for each washing. Then $250 \mu$ of elution buffer was added to the column and incubated for $5 \mathrm{~min}$ with gentle rocking. After centrifugation, bound proteins were removed by the elution buffer (= elution fraction). Each sample was then analyzed by SDS-PAGE (Fig. 3). The elution fraction yielded bands of 50.8 and 17.6 $\mathrm{kDa}$ indicating that the P50 of ACLSV had captured the 17.6 $\mathrm{kDa}$ PR-10 protein (Fig. 3, lane 6) and the protein PR-10 was confirmed by sequencing (data not shown). To exclude nonspecific binding, TBS was used as bait and PR-10 was used as prey protein in the pull-down assay as negative control, excluding PR-10 own affinity to the His resin (Fig 3, lane 7 ). The protein products expressed by the cells transformed with the empty pET21a vectors were used as prey protein and P50 was used as bait in the pull-down assay as another negative control (data not shown).

Plant viruses spread systemically by cell-to-cell movement through plasmodesmata and are transported on longdistances through the plant's vascular system (Carrington et al., 1996; Lazarowitz, 1999). ACLSV P50 is assigned to the $30 \mathrm{~K}$ superfamily of virus movement proteins (Mushegian and Koonin, 1993). It has two independently active,

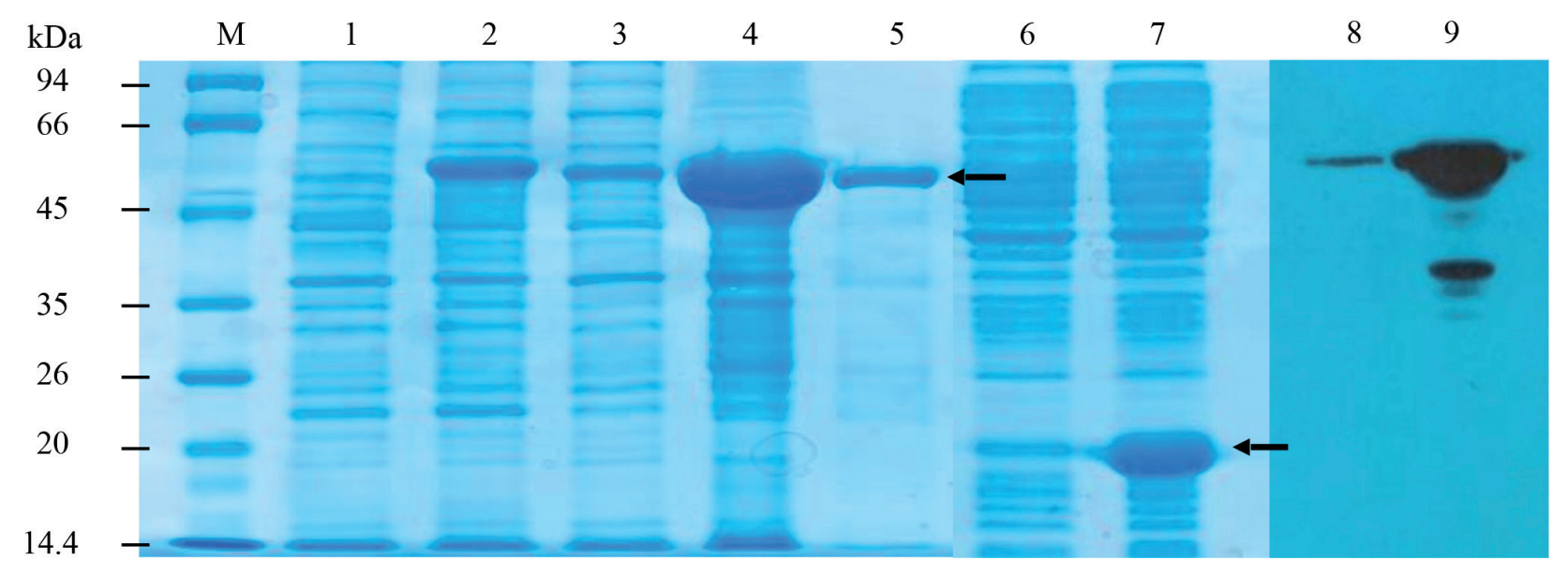

Fig. 2

Expression and purification of the P50 protein of ACLSV and PR-10 from Malus sylvestris

$12 \%$ SDS-PAGE profile of total extracts of $E$. coli Rosetta (DE-3) containing plasmid pET21a-P50, lane 1: uninduced; lane 2: induced by 0.1 mmol/1 IPTG; lane 3: supernatant after sonication; lane 4: precipitate after sonication; lane 5: purified lysate. 12\% SDS-PAGE profile of total extracts of E. coli Rosetta (DE-3) containing plasmid pET21a- PR-10, lane 6: uninduced; lane 7: induced by $0.1 \mathrm{mmol} / \mathrm{l}$ IPTG. Western blot analysis of ACLSV P50 protein by HisHRP, lane 8: uninduced; lane 9: after induction. M: Marker. 


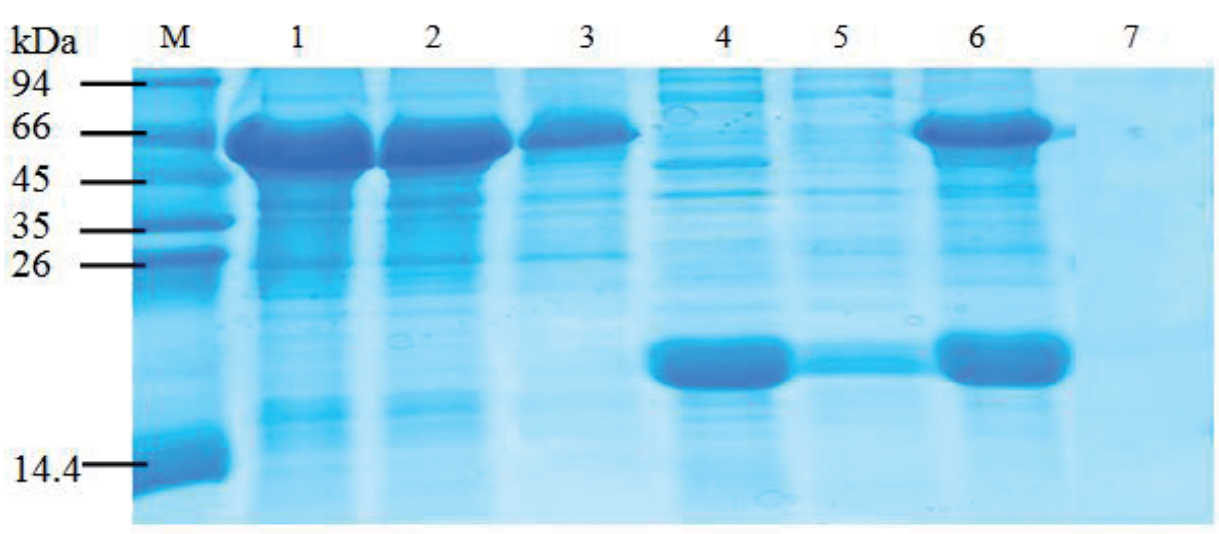

Fig. 3

Pull-down assay of the interaction between the P50 of ACLSV and PR-10 of Malus sylvestris

Pull-down assay of, lane 1: bait protein P50; lane 2: bait protein P50 flow-through; lane 3: supernatant of denatured bait protein-resin; lane 4: prey protein PR-10; lane 5: prey protein PR-10 flow-through; lane 6: elution of bait protein P50 and prey protein PR-10; lane 7: negative control (TBS as bait and PR-10 as prey protein). M: Marker.

single-stranded nucleic acid-binding domains (Isogai and Yoshikawa, 2005). Two general mechanisms of action are employed by the $30 \mathrm{~K}$ superfamily. The first is a tobacco mosaic virus (TMV)-like mechanism that transports viral genomic RNA with a movement protein through plasmodesmata, without extensive structural modifications (Carrington et al., 1996; Deom et al., 1992; Lazarowitz and Beachy, 1999; Lazarowitz, 1999; Lucas et al., 1993), while the second mechanism is tubule based mechanism which moves complete virions along newly formed tubular structures. In addition to the movement protein function, recent work has revealed that P50 also functions as a silencing suppressor and inhibits systemic silencing in N. benthamiana (Yaegashi et al., 2007).

Until now, most research on ACLSV had focused on the virus itself and little is known about its interaction with host factors. Though many functions of P50 have been reported, there is no experimental evidence indicating a physical interaction between P50 and host factors involved in the plant's immune response. The results of our study, however, suggest that PR-10 from M. sylvestris cv. R12740-7A interacts directly with the P50 of ACLSV.

The PR-10 family is one of the most important families among the 17 pathogenesis-related protein families. PR-10 proteins are different from most other PR proteins, as they are typically small, acidic, cytosolic molecules with a conserved three-dimensional structure (Liu and Ekramoddoullah, 2006; Liu et al., 2006; Xie et al., 2010; Ziadi et al., 2001). Two ginseng PR-10 proteins showed RNase activity, and other members of the PR-10 family displayed RNA-degrading activities (Moiseyev et al., 1997; Bantignies et al., 2000; Kim et al., 2008). In addition, CaPR-10 isolated from hot pepper (Capsicum annuum) was demonstrated to display RNase activity and is involved in antiviral processes in vitro directly (Park et al., 2004).

New evidence reveals that PR-10 proteins posses also some other functions (Koistinen et al., 2005; Radauer et al., 2008; Sikorski et al., 1999; Wen et al., 1997). For example, Wang et al. (1999) reported that PR-10 genes in lilies (Lilium spp.) are induced by abscisic acid (ABA) and methyl jasmonate (MeJA), two separate signal transduction pathways found in the plant's anthers and other organs (Wang et al., 1999). Several proteins interacting with VpPR-10.1 protein from Chinese grapevine (Vitis pseudoreticulata) included CNR8, UFGT6, HSP, DEAD-box, Trx h2, Grx C9 and GLOX. These proteins are closely related to the plant's defensive action against pathogens and also abiotic stress. The grapevine study also suggested that the VpPR-10.1 gene may be involved in hormone signaling, programmed cell death, and defense responses of the plant (Xu et al., 2013). Another study showed that the PR-10 protein CaARP functions as an aldo/keto reductase to scavenge cytotoxic aldehydes (Jain et al., 2015). Leucine-rich repeat 1 (LRR1) protein interaction with CaPR-10, enhanced HR-like cell death phenotype and activated defense signaling (Choi et al., 2012). A positive transcription factor, WRKY b, was shown to bind the PR10 promoter and activated the defense signaling pathway in pepper (Capsicum annuum) (Lim et al., 2011).

Several viruses can trigger a PR-10 response in their hosts (Park et al., 2004; Pinto and Ricardo, 1995; Puhringer et al., 2000; Xu et al., 2003). The CaPR-10 protein existed at low levels in the leaf tissue of hot pepper (C. annuum), but was dramatically induced when plants were inoculated with TMV- $\mathrm{P}_{0}$. This increase correlated with an elevated ribonucleolytic activity (Park et al., 2004). Cucumber mosaic virus (CMV) and D satRNA (CMV/D satRNA) infected 
tomato plants showed specifically activated transcription of several tomato defense-related genes, including PR-10 (Xu et al., 2003). The promoter sequence of Ypr10*a from Malus domestica has been isolated and characterized. Ypr10*a-GUS transgenic expression in transformed tobacco plants was strongly induced following inoculation with TMV and two potyviruses, tobacco etch virus and tobacco vein mottling virus (Satoh et al., 2000).

All researches showed that PR-10 might play a great role in the resistance of plant against virus. Until now, little information is available for the function of PR-10 in Malus plants. In this study, we found that PR-10 from M. sylvestris cv. R12740-7A interacted directly with the P50 of ACLSV. Our results provide a basis for the biological function of M. sylvestris cv. R12740-7A PR-10 in the ACLSV infection process and an interacting mechanism between host and virus. Although the pull-down assay indicated the interaction in vitro, it may not occur in living plant cells. Therefore, additional experiments, such as bimolecular fluorescence complementation, co-immunoprecipitation, and the localization of P50 and PR-10 in ACLSV-infected plants by immunoelectron microscopy, should be performed to provide additional lines of evidence for their interaction.

Acknowledgements. We thank Professor John Hu for his insights and critical review of this manuscript. Financial support was provided by research funds from National Nature Science Foundation (31201487), China Agricultue Research System (Cars-28), Hebei Nature Science Foundation (C2013204058), Hebei Natural Science Foundation of Higher Education Institutions for Youth (YQ2014023) and the support plan for youth talent in Hebei province.

\section{References}

Bantignies B, Seguin J, Muzac I, Dedaldechamp F, Gulick P, Ibrahim R (2000): Direct evidence for ribonucleolytic activity of a PR-10-like protein from white lupin roots. Plant Mol. Biol. 42, 871-881. https://doi.org/10.1023/ A:1006475303115

Brunt AA, Crabtree K, Dallwitz MJ, Gibbs AJ, Watson L (1996): Viruses of plants. Description and lists from the VIDE Database. Wallingford, UK.

Carrington JC, Kasschau KD, Mahajan SK, Schaad MC (1996): Cell-to-cell and long-distance transport of viruses in plants. Plant Cell 8, 1669-1681. https://doi.org/10.1105/ tpc.8.10.1669

Choi DS, Hwang IS, Hwang BK (2012): Requirement of the cytosolic interaction between pathogenesis-related protein 10 and leucine-rich repeat protein 1 for cell death and defense signaling in pepper. Plant Cell 24, 1675-1690. https:// doi.org/10.1105/tpc.112.095869

Deom CM, Lapidot M, Beachy RN (1992): Plant virus movement proteins. Cell 69, 221-224. https://doi.org/10.1016/00928674(92)90403-Y
Desvignes JC, Boyé R (1989): Different diseases caused by the chlorotic leaf spot virus on the fruit trees. Acta Hortic. 235, 31-38. https://doi.org/10.17660/ActaHortic.1989.235.3

Desvignes JC, Boyé R, Cornaggia D, Grasseau N (1992): Quick detection of the principal apple and pear virus diseases. Acta Hortic. 309, 377-384. https://doi.org/10.17660/ ActaHortic.1992.309.56

Duan H, Zhao X, Zhong M, Hu T, Wang S, Zhang Y, Zhang X, Wang Y, Cao K (2014): Construction and evaluation of yeast two-hybrid cDNA library of Malus sylvestris cv. R12740-7A. J. Agric. Univ. Hebei 37, 69-73.

German S, Candresse T, Lanneau M, Dunez J (1992): Genomic organization of Apple chlorotic leaf spot closterovirus (ACLSV). Acta Hortic. 309, 31-38. https://doi. org/10.17660/ActaHortic.1992.309.2

German SV, Candresse T, Lanneau M, Huet JC, Pernollet JC, Dunez J (1990): Nucleotide sequence and genomic organization of apple chlorotic leaf spot closterovirus. Virology 179, 104-112. https://doi.org/10.1016/0042$\underline{6822(90) 90279-Z}$

Isogai M, Yoshikawa N (2005): Mapping the RNA-binding domain on the apple chlorotic leaf spot virus movement protein. J. Gen. Virol. 86, 225-229. https://doi.org/10.1099/ vir.0.80493-0

Isogai M, Saitou Y, Takahashi N, Itabashi T, Terada M, Satoh H, Yoshikawa N (2003): The 50-kDa Protein of apple chlorotic leaf spot virus interferes with intracellular and intercellular targeting and tubule-inducing activity of the $39 \mathrm{kDa}$ protein of grapevine berry inner necrosis virus. Mol. Plant Microbe Interact. 16, 188-195. https://doi. org/10.1094/MPMI.2003.16.3.188

Jain D, Khandal H, Khurana JP, Chattopadhyay D (2015): A pathogenesis related-10 protein CaARP functions as aldo/ keto reductase to scavenge cytotoxic aldehydes. Plant Mol. Biol. 90, 171-187. https://doi.org/10.1007/s11103015-0405-Z

Kim ST, Yu S, Kang YH, Kim SG, Kim J, Kim S, Kang KY (2008): The rice pathogen-related protein 10 (JIOsPR-10) is induced by abiotic and biotic stresses and exhibits ribonuclease activity. Plant Cell. Rep. 27, 593-603. https:// doi.org/10.1007/s00299-007-0485-6

Koistinen KM, Soininen P, Venalainen TA, Hayrinen J, Laatikainen R, Perakyla M, Tervahauta A, Karenlampi S (2005): Birch PR-10c interacts with several biologically important ligands. Phytochemistry 66, 2524-2533. https://doi. org/10.1016/j.phytochem.2005.09.007

Lazarowitz SG, Beachy RN (1999): Viral movement proteins as probes for intracellular and iIntercellular trafficking in Plants. Plant Cell 11, 535-548. https://doi.org/10.1105/ tpc.11.4.535

Lazarowitz SG (1999): Probing plant cell structure and function with viral movement proteins. Curr. Opin. Plant Biol. 4, 332-338. https://doi.org/10.1016/S1369-5266(99)80058-2

Lim JH, Park CJ, Huh SU, Choi LM, Lee GJ, Kim Y J, Paek K (2011): Capsicum annuum WRKYb transcription factor that binds to the CaPR-10 promoter functions as a positive regulator in innate immunity upon TMV infection. Bio- 
chem. Biophys. Res. Commun. 411, 613-619. https://doi. org/10.1016/j.bbrc.2011.07.002

German-Retana S, Bergey B, Delbos RP, Candresse T, Dunez J (1997): Complete nucleotide sequence of the genome of a severe cherry isolate of apple chlorotic leaf spot trichovirus (ACLSV). Arch. Virol. 142, 833-841. https://doi. org/10.1007/s007050050122

Liu J, Ekramoddoullah AK (2006): The family 10 of plant pathogenesis-related proteins, their structure, regulation, and function in response to biotic and abiotic stresses. Physiol. Mol. Plant P. 68, 3-13. https://doi.org/10.1016/j. pmpp.2006.06.004

Liu X, Huang B, Lin J, Fei J, Chen Z, Pang Y, Sun X, Tang K (2006): A novel pathogenesis-related protein (SsPR-10) from Solanum surattense with ribonucleolytic and antimicrobial activity is stress-and pathogen-inducible. J. Plant Physiol. 163, 546-556. https://doi.org/10.1016/j.jplph.2005.04.031

Lucas WJ, Ding B, Schoot C (1993): Tansley review No. 58 plasmodesmata and the supracellular nature of plants. New Phytol. 125, 435-476. https://doi.org/10.1111/j.14698137.1993.tb03897.x

Moiseyev GP, Fedoreyeva LI, Zhuravlev YN, Yasnetskaya E, Jekel PA, Beintema JJ (1997): Primary structures of two ribonucleases from ginseng calluses - new members of the PR-10 family of intracellular pathogenesis-related plant proteins. FEBS Letters 407, 207-210. https://doi. org/10.1016/S0014-5793(97)00337-2

Mushegian AR, Koonin EV (1993): Cell-to-cell movement of plant viruses, insights from amino acid sequence comparisons of movement proteins and from analogies with cellular transport systems. Arch. Virol. 133, 239-257. https://doi. org/10.1007/BF01313766

Németh M (1986): Viruses, mycoplasma and rickettsia diseases of fruit trees. Dordrecht; Boston, M. Nijhoff; Hingham, MA, USA.

Park C, Kim K, Shin R, Park JM, Shin Y, Paek K (2004): Pathogenesis-related protein 10 isolated from hot pepper functions as a ribonuclease in an antiviral pathway. Plant J. 37, 186-198. https://doi.org/10.1046/j.1365-313X.2003.01951.x

Pinto M, Ricardo C (1995): Lupinus albus L. Pathogenesis-related proteins that show similarity to $\mathrm{PR}-10$ proteins. Plant Physiol. 109, 1345-1351. https://doi.org/10.1104/ pp.109.4.1345

Puhringer H, Moll D, Hoffmann-Sommergruber K, Watillon B, Katinger H, Machado ML (2000): The promoter of an apple Ypr10 gene, encoding the major allergen Mal d 1, is stress- and pathogen-inducible. Plant Sci. 152, 35-50. https://doi.org/10.1016/S0168-9452(99)00222-8

Radauer C, Lackner P, Breiteneder H (2008): The Betv 1 fold, an ancient, versatile scaffold for binding of large, hydrophobic ligands. Bmc. Evol. Biol. 8, 286. https://doi. org/10.1186/1471-2148-8-286

Satoh H, Matsuda H, Kawamura T, Isogai M, Yoshikawa N, Takahashi T (2000): Intracellular distribution, cell-to-cell trafficking and tubule-inducing activity of the $50 \mathrm{kDa}$ movement protein of apple chlorotic leaf spot virus fused to green fluorescent protein. J. Gen. Virol. 81, 2085-2093. https://doi.org/10.1099/0022-1317-81-8-2085
Sikorski M, Biesiadka J, Kasperska AE, Kopcińska J, Łotocka B, Golinowski W, Legocki AB (1999): Expression of genes encoding PR-10 class pathogenesis-related proteins is inhibited in yellow lupine root nodules. Plant Sci. 149, 125-137. https://doi.org/10.1016/S0168-9452(99)00148-X

Wang CS, Huang JC, Hu J (1999): Characterization of two subclasses of PR-10 transcripts in lily anthers and induction of their genes through separate signal transduction pathways. Plant Mol. Biol. 40, 807-814. https://doi.org/10.1023/ $\underline{\text { A:1006285028495 }}$

Waterworth H (1993): Processing foreign plant germ plasm at the national plant germplasm quarantine center. Plant Dis. 77, 854-860. https://doi.org/10.1094/PD-77-0854

Wen J, Vanekkrebitz M, Hoffmann-Sommergruber K, Scheiner O, Breiteneder H (1997): The potential of Betv1 homologues, a nuclear multigene family, as phylogenetic markers in flowering plants. Mol. Phylogenet. Evol. 8, 317-333. https://doi.org/10.1006/mpev.1997.0447

Xie Y, Chen Z, Brown RL, Bhatnagar D (2010): Expression and functional characterization of two pathogenesis-related protein 10 genes from Zea mays. J. Plant Physiol. 167, 121-130. https://doi.org/10.1016/j.jplph.2009.07.004

Xu P, Blancaflor EB, Roossinck MJ (2003): In spite of induced multiple defense responses, tomato plants infected with cucumber mosaic virus and D satellite RNA succumb to systemic necrosis. Mol. Plant Microbe Interact. 16, 467-476. https://doi.org/10.1094/MPMI.2003.16.6.467

Xu TF, Xiang J, Li F, Li T, Yu Y, Wang Y, Xu Y (2013): Screening proteins interacting with VpPR-10.1 of Chinese wild grapevine using the yeast two-hybrid system. Acta Physiol. Plant 35, 2355-2364. https://doi.org/10.1007/ s11738-013-1269-y

Yaegashi H, Takahashi T, Isogai M, Kobori T, Ohki S, Yoshikawa N (2007): Apple chlorotic leaf spot virus $50 \mathrm{kDa}$ movement protein acts as a suppressor of systemic silencing without interfering with local silencing in Nicotiana benthamiana. J. Gen. Virol. 88, 316-324. https://doi.org/10.1099/vir.0.82377-0

Yaegashi H, Tamura A, Isogai M, Yoshikawa N (2008) Inhibition of long-distance movement of RNA silencing signals in Nicotiana benthamiana by apple chlorotic leaf spot virus $50 \mathrm{kDa}$ movement protein. Virology 382, 199-206. https://doi.org/10.1016/j.virol.2008.09.024

Yoshikawa N, Oogake S, Terada M, Miyabayashi S, Ikeda Y, Takahashi T, Ogawa K (1999): Apple chlorotic leaf spot virus $50 \mathrm{kda}$ protein is targeted to plasmodesmata and accumulates in sieve elements in transgenic plant leaves. Arch. Virol. 144, 2475-2483. https://doi.org/10.1007/s007050050660

Yoshikawa N, Saitou Y, Kitajima A, Chida T, Sasaki N, Isogai M (2006): Interference of long-distance movement of grapevine berry inner necrosis virus in transgenic plants expressing a defective movement protein of apple chlorotic leaf spot virus. Phytopathology 96, 378-385. https:// doi.org/10.1094/PHYTO-96-0378

Ziadi S, Poupard P, Brisset M, Paulin J, Simoneau P (2001): Characterization in apple leaves of two subclasses of PR-10 transcripts inducible by acibenzolar-S-methyl, a functional analogue of salicylic acid. Physiol. Mol. Plant P. 59, 33-43. https://doi.org/10.1006/pmpp.2001.0343 